\title{
Psychobehavioral and psychosocial aspects of neuropathic pain patients
}

\author{
Aspectos psicocomportamentais e psicossociais dos portadores de dor neuropática
}

Dirce Maria Navas Perissinotti ${ }^{1}$, Andrea Golfarb Portnoi ${ }^{2}$

DOI 10.5935/1806-0013.20160055

\begin{abstract}
BACKGROUND AND OBJECTIVES: Identifying and treating psychosocial, intrapsychic, relational, psychiatric and psychobehavioral factors which influence neuropathic pain nature, severity and persistence are object of scientific concern and a lot has been done in this area; however it is clear the need for further emphasis and disclosure of contents for better professional knowledge. This study aimed at outlining the psychobehavioral and psychosocial scenario by means of literature review, through some theories about pain regulation, via cognitive functioning and stress theories, although it is known that the universe of this study is too broad but the idea is to outline a panoramic view of the field. CONTENTS: Incapacity, distress, painful and unhealthy behaviors and of gains are challenging factors for the treatment of neuropathic pain patients. Notions about thinking distortion, especially caused by pain perception leading to catastrophic thoughts and decreasing the efficacy of other non-addressed interventions, as well as aspects of the psychosocial impact influencing the development of chronicity and maintenance of unhealthy patterns.

CONCLUSION: Psychological interventions aiming at changing beliefs and dysfunctional behaviors, incapacities and distress, at changing neuropathic pain perception, treatment of mental decompensations such as depression and anxiety and of recurrences, are critical to manage neuropathic pain patients. It is confirmed that knowledge about adaptations in the rewarding circuits is fundamental for psychological, psychotherapeutic and psychosocial interventions to be more effective, thus preventing problems related to pathological maintenance in cases of neuropathic etiology.
\end{abstract}

Keywords: Cognitive functions, Mental processes, Neuropathic pain, Psychobehavioral factors, Psychosocial factors, Stress.

\section{RESUMO}

JUSTIFICATIVA E OBJETIVOS: Identificar e tratar os fatores psicossociais, intrapsíquicos, relacionais, psiquiátricos e psicocomportamentais que influenciem a natureza, gravidade, persistência da dor neuropática, vem sendo objeto de preocupaçáo científica e muito se tem progredido na área, no entanto, é vigente a necessidade de maior ênfase e divulgaçấo dos conteúdos para melhor conhecimento no meio profissional. O presente artigo visou esboçar o panorama da área psicocomportamental e psicossocial, por meio de levantamento da literatura, através de algumas teorias acerca da regulaçáo de dor, via teorias do funcionamento cognitivo e estresse, embora sabidamente o universo de estudo seja muito amplo, pretende esboçar uma visão panorâmica do campo.

CONTEÚDO: A incapacidade, o sofrimento, os comportamentos dolorosos e doentios e dos ganhos são fatores de desafio aos tratamentos do doente com dor neuropática. Noçôes acerca da distorção do pensamento, particularmente, decorrente da percepçáo da dor induzindo a pensamentos catastróficos reduzindo a eficácia de outras intervençôes nấo abordadas, bem como aspectos da visão do impacto psicossocial que intervêm no desenvolvimento da cronificação e manutenção de padrôes doentios.

CONCLUSẪ: As intervençôes psicológicas ao visarem à alteração das crenças e

1. Atividade em consultório privado, Diretora Administrativa da Sociedade Brasileira para o Estudo da Dor-SBED. São Paulo, SP, Brasil.

2. Psicoterapeuta, coordenadora da área de Psicologia da Liga de Dor FMUSP-EEUSP-HC. Colaboradora do Centro Multidisciplinar de Dor da Clínica Neurológica, do HC-FMUSP. São Paulo, SP, Brasil.

Conflict of interests: none - Sponsoring sources: none.

Correspondence to:

Rua Teodoro Sampaio, 352 cj. 24 - Pinheiros

05406-000 São Paulo, SP, Brasil.

E-mail: dircelko@gmail.com

(C) Sociedade Brasileira para o Estudo da Dor modificaçáo dos comportamentos disfuncionais, incapacidades e sofrimentos, alteraçáo da percepçấo da dor neuropática, tratamento das descompensaçôes mentais como a depressão e a ansiedade e das recidivas tornam-se imperativas no manejo do doente com a condiçấo. Confirma-se que o conhecimento acerca de adaptaçôes nos circuitos de recompensa é fundamental para que as intervençóes psicológicas, psicoterapêuticas e psicossociais possam agir de maneira mais eficaz prevenindo problemas relacionados à manutençâo patológica nos casos de etiologia neuropática.

Descritores: Dor neuropática, Estresse, Fatores psicocomportamentais, Fatores psicossociais, Funçóes cognitivas, Processos mentais.

\section{INTRODUCTION}

Psychological, psychobehavioral and psychosocial factors play relevant role in pain perception and its reactions interfering with central afferent stimuli neuromodulation ${ }^{1,2}$. Psychological approaches have major impact on the understanding and treatment of painful patients and on the way they communicate their behaviors or iatrogenizing conducts.

Recommending that psychological approaches should not be considered alternatives, but rather be integrated as part of a comprehensive approach to treat patients with chronic neuropathic pain and psychological comorbidities, Turk at al. ${ }^{3}$ state that some diagnostic dilemmas are created;

"(...) such patients require the consideration of additional treatment to optimize results. Regardless of being cause or effect, psychiatric comorbidities and psychosocial problems may exacerbate and negatively affect neuropathic pain intensity, disease progression, patients' adaptation and responses to treatment. So, it is proposed that the success of the treatment of most chronic neuropathic pain patients should adopt an integrated multimodal approach with tailored prescription, rather than pharmacological therapies ${ }^{3}$.

So, it is necessary to understand the meaning of symptoms in the context in which they occur and to have major tolerance with complaints expression so that they are useful for general treatment purposes. Negative attitudes should be taken with flexibility aiming at their use to favor therapeutic methods, to rapidly discover and accept patients' needs and objectives, availability to play the role of guide or counselor, adopting a more active role ${ }^{4}$.

To systematize this study, three types of pain are distinguished: physical pain, adverse state related to actual or potential injuries and diseases; social pain, adverse emotion associated to social exclusion; and psychological pain, negative emotion induced by loss of stimulation and fear feeding back the pain cycle.

With regard to psychological pain which we shall call suffering ${ }^{5}$, there are few data in non humans and, for humans, in addition to psychoanalytic literature, little has been written so it will not be addressed in this article. The meaning of daily life and psychological pain ${ }^{6}$ is centered in the discussion of results from two procedures involving loss of stimulation, or motivation, unexpected devaluation of reward and extinction, or the unexpected omission of a reward ${ }^{7}$. There are some differences and interactions between physical and psychological pains which contribute for the multidimensional pain experience.

Pain has survival value, since it is an alert that something is not well, often signaling injury or disease, especially in case of neuropathic pain, the definition of which is pain triggered by nervous system injury or dysfunction, that is, resulting from abnormal activation of the nociceptive pathway (small fibers and spinothalamic tract) and which, differently from nociceptive pain, is that especially triggered by physiological activation of receptors, or painful pathway and is related to bone, muscle or ligament tissues injury ${ }^{8-10}$.

It is known by concept that the division in nociceptive or neuropathic pain is for diagnostic precision objectives and that, clinically, in several cases this distinction is not so clear, since what happens is the coexistence of both and that, in fact, there would be predominance of one over the other ${ }^{11,12}$.

Psychological factors which previously were admitted as 'reactions to pain' now are seen as integral part of the painful process and considered an al- 
ternative to handle such condition ${ }^{13}$. And, for long it has been recognized that pain management, from psychological science point of view, is a major control component. Psychological management is based on getting relief through active patients' participation, encouraging them to adopt healthcare practices, in addition to fostering active participation in psychosocial sphere. The old dilemma of whether psychobehavioral problems would be cause or reaction is still to be defined ${ }^{3}$.

Suffering and not sensation may lead to helplessness and hopelessness, two feelings which easily induce depression. Re-experience avoidance, anticipation and fear are maladapted coping attempts which often add to discomfort elements inducing to the unbearable and being translated into anxiety.

In 2009 , a comment was published ${ }^{14}$, with the title Neuropathic pain management is more than pills, which helps understanding the subject, because it emphasizes the hypothesis based on historic investigation justification based on associative learning and is rooted in two nuclear hypotheses: (1) that pain may be considered a response and not only a stimulus and (2) this unsurprisingly coded non nociceptive information "coincides" with nociceptive inputs, supporting response to subsequent similar events ${ }^{15}$.

There is a complex relationship between physiological stress response and chronic pain symptoms. Their treatment, partially and unfortunately, are not always adequate and often induce to worsening with clinical results not always benefiting patients. It is very urgent that new techniques are developed to treat such patients ${ }^{16}$

\section{PSYCHOLOGICAL APPROACH: FROM DIAGNOSIS TO INTER- VENTION}

In theory, everyone has skills or potential to develop sensations coping strategies, which in this case is the painful sensation, through the management of mental processes to deal with the experience coming from the nociceptive system.

No treatment described to date is successful in totally eliminating pain ${ }^{3}$, and it is not desirable that this happens; as a consequence, it is necessary that most people adapt to the presence of chronic pain and learn self-management in face of such persistent stimulus and its consequences. However, this seems to be the most complicated part of such patients' management. There is a tenuous limit between desirable comfort and possible treatment.

Mental health professionals approach aims at rehabilitation, reintegration and reinsertion of patients in functional roles previously played in their daily lives or, when this is not possible, their reorientation toward new activities. It is also proposed the identification and treatment of psychosocial, intrapsychic, relational, psychiatric and behavioral factors which influence pain nature, severity and persistence, the underlying disease, incapacities, suffering, painful and ill behaviors and gains, be them primary, secondary or tertiary. It is up to mental health professionals to identify, through diagnostic evaluation process, the baseline maladjustment, treat causes of emotional imbalance, be it from social interactions, or propose individual cognitive or psychoaffective reorganization with regard to psychosocial relationship, helping promoting, when possible, changes in patients' personality structure, as well as better adapted strategies to cope with problem situations.

Demands should be minimized or adapted to patients' actual conditions, who should also be helped to overcome daily problems. When not possible, one should invest in decreasing the impact of social and environmental factors which are out of control.

Diagnostic evaluation in this area is broad and encompasses several sub-areas, being all of them complementary and supplementary. There is medical diagnosis, where psychic evaluation by the psychiatrist defines the psychopathological situation and the search for a descriptive nosographic picture.

There is the psychologist diagnosis, technically called psychodiagnosis which, for didactic purposes shall be subdivided in axes with established objectives, as follows: a) focusing on patients' position with regard to the disease, reactive; b) obtaining a panoramic view of patients' lives, considering areas influencing or being influenced by the disease, or situational: psychic, social and cultural functioning; c) evaluating relationships established by patients as from the disease, how people projectively relate, that is, transferential; d) examining mental life areas, such as cognitive and its functions (neuropsychologic evaluation, exclusively) and/or affective-emotional (included personality structure and dynamics diagnosis), that is, functional; and e) analyzing relational life in different groups in which the individual participates, that is, psychosocial.
Psychological interventions objective basically aims, in addition to education, at supplying problem-related information, changing beliefs and modifying dysfunctional behaviors, decreasing avoidance, incapacities and suffering, at changing neuropathic pain perception, treating mental decompensations, such as depression and anxiety, changing fantasies and unjustified fears, decreasing or increasing aggressiveness, hostility and conflicts of patients with the healthcare team and their families, or with significant escorts, decreasing family discomfort, decreasing the possibility of self-aggression, suicide and recurrences ${ }^{17}$

These are noninvasive methods and represent minimum risk for patients, but require their active involvement. They demand more time of patients and professionals - classically between 8 and 12 sessions lasting one hour each - and need formal and structured establishment of a working agreement. It is also part of this evaluation to check the presence of stressors and triggering factors, to evaluate the relevance of psychosocial, intrapsychic, relational and behavioral factors interference in the origin, severity and maintenance, incapacities and dysfunctional painful behaviors.

It is necessary to check how they affect life and to identify which personal, environmental and cultural factors may influence the meaning given to painful event, since the idiosyncratic component attributed to it helps the increment of numerous noxious situations.

\section{MENTAL PROCESSES AND COGNITIVE FUNCTIONS}

Pain only exists as "we perceive it", that is, if by chance mind (consciousness) does not perceive it, pain does not exist ${ }^{18}$.

So, pain perception is determinant in any pain complaint, be it acute or chronic. The question is which would be the best management for its perception to be able to induce patients to better results with regard to pain relief. So, one proposal of psychological work with such patients is generally related to induce perception changes ${ }^{19}$, among others painful perception, until significant relief is reached. "Pain experience is implanted in memory and continues to torture patients even after having treated the disease" ${ }^{20}$.

Somatosensory memory would manifest through minor changes in cortex S1, contributing for pain magnification, even in the absence of peripheral stimulation. Psychological processes, especially attentional processes, help the fixation of additional mnemonic contents which would be further spread, thus reinforcing those already existing, in addition to local cortex changes. In chronic states, these increases would be associated to cortical excitation, which may significantly contribute to local cortical reorganization ${ }^{20}$.

When stating that neuropathic pain is a perceptive phenomenon, one is saying that neuropathic pain is a subjective experience. When talking about neuropathic pain experience, one is talking about the way the perceptive phenomenon allows - or not - the access to consciousness which is not always lucid. The awareness of neuropathic pain experience has direct effect on muscle tone control, on attentive processing (salience effect) and on its interpretation, in addition to biological trigger, because it is known that any pain, even originating from social rejection experience, takes root on the central and peripheral neuroanatomic base ${ }^{21-23}$.

Neuropathic pain is associated to primary and motor somatosensory cortex reorganization, as well as to anterior cingulate cortex and insula. The difficulty of patients to adapt to organizational changes would increase with chronicity; in phantom limb pain and other neuropathic pain syndromes, cortical reorganization is correlated to its magnitude ${ }^{24}$ and the same would be true for other etiologies.

The development, the shape of each one's experience, with their idiosyncrasies, derived judgments, expectations formed after judgments and suffering are characteristics of "an emerging human brain property and these are those depending on consciousness" 25 . Because pain is a sensation and suffering is the whole interpretation given and which usually follows this sensation and has remained apart from consciousness. Thoughts like "this is killing me", or "I cannot take it anymore", or "This is destroying my life (day, moment)", or "Why is this happening to me?" are judgments feeding suffering which tend to increase perceived sensation intensity ${ }^{23}$.

Pain is a conscious experience and does not exist outside consciousness ${ }^{25,26}$. The illustrative statement by Erdelyi ${ }^{27}$, "I" See Through the Lens of "Me", when translated looses the emphatic value which expresses the movement of the antagonist definition, close and at the same time distant, that has the notion of awareness. In this article, the movement between I and $\mathrm{Me}$ is better expressed when patients refer to symptoms. However, to the observer 
who not always pays attention to these peculiarities, this might seem strange. Narrative dimension may and should be observed ${ }^{5}$.

It is well-established that pain chronicity impairs cognitive processing, especially memory, attention and mental flexibility ${ }^{28}$. Overlays were found among brain regions involved in pain modulation and cognition, especially including pre-frontal cortex and anterior cingulate cortex, which are involved in executive function, attention and memory.

In surgical patients prospectively followed up and with pre-surgery pain, a longitudinal prospective study was carried out to investigate relationships among executive function, visual memory and attention, evaluated by clinical measurements and chronic pain development, its severity and neuropathic symptoms (based on "Neuropathic Pain" questionnaire) between 6 and 12 months after surgery (total knee arthroplasty to repair osteoarthritis and breast cancer surgery).

Neuropsychological tests have evaluated immediate remembrance, cognitive flexibility, visual processing and visual memory, in addition to coping strategies, depression and anxiety. In total, 189 patients were evaluated being 96 re-evaluated at 6 months and 88 at 12 months. Total results of followed up patients have found significant pain at 6 and 12 months (pain intensity) evaluated by poorer cognitive performance and recall, regardless of affective variables.

Analyses of less expressive scores have shown pain intensity and neuropathic symptoms, although the strength of the association was less robust for neuropathic symptoms. Authors state that results were not affected by the type of surgery or preoperative pain and that similar conclusions were obtained specifically for patients who initially had no pain. As conclusion, they state that results support, for the first time, the notion that pre-morbid limitation of cognitive flexibility and memory capacity could be linked to pain chronicity mechanisms and probably also to its quality.

That is, patients with executive functioning or memory deficits due to functional brain conditions, would be at higher risk of chronicity after a painful event ${ }^{29}$.

Logic discrepancies were identified, such as related to anterior cingulate cortex functioning ability which would feed back pre-frontal activation ${ }^{22}$ and, in adverse conditions such as chronic pain, would be reversely activated with regard to anterior cingulate inducing further difficulty for inhibitory control related to stress intensity contention ability. In practical terms one should say that conscious understanding of the alert condition proposed by pain sensation would be misrepresented, being magnified in some cases and clouded or slowed down in others.

With this, treatment under this perspective involves the awareness of the way how thinking impacts pain experience and it is expected that there is learning leading to change in interpretation which, in turn, would decrease suffering. However, sometimes it is necessary to give patients a more objective voice to the experiences to make them aware of what they are thinking, for them to understand that reality is not unique, that is, it may vary according to circumstances.

Psychological interventions, as well as psychotherapy, are the road for this reorganization, since they would act on mind on "the way to deal with information without generating deliberate attitudes"30, that is, the way how they perform mental work. With this, chronic pain patients who would have less perceptive acuity for body image components (for dimension and alignment of body parts) and less ability to mentally visualize and foresee painful regions maneuvers ${ }^{25}$, and such condition would not be explainable by deficits related to working memory of executive functions ${ }^{31}$, although both conditions have been more commonly identified in chronic patients as compared to healthy controls ${ }^{32-34}$.

The affective experience, which includes emotions and their relationships with pain, may be regulated aiming at maintaining physical and mental health, being that its mechanisms are being studied especially since the $1990 s^{35}$. Self-regulatory mechanisms use brain strategies and processes which may be mutually influenced ${ }^{36}$.

Currently, some theories about pain regulation are based on cognitive and emotion theories. In the former, the idea is that they act modifying cognitive processes which follow primary affective states by means of ascending or descending signals, in addition to brain ascending nociceptive signals. They refer to past noxious facts and situations which teach what to avoid in the future and motivate to act in a way to find an objective.

People born unable to feel pain, often do not live beyond childhood because the lack of pain protective function, when acute, relatively short experience, with limited period of time, when there is wound and healing or when the disease is cured cur $^{37,38}$.

The role of pain is to delimit a "before" and an "after" about an event. Delimiting action temporality supports the perspective of consequence in the lives of individuals. The function of time, or the function of temporality, allows along life to put in context the consequences and strategies to manage better behavioral responses.

Thinking distortion caused by pain perception may lead to catastrophizing feelings which may decrease the efficacy of other interventions. A study evaluating catastrophizing ${ }^{39}$ in 82 individuals with neuropathic pain in the beginning of a clinical trial to evaluate the efficacy of topical analgesics has observed that high scores in catastrophizing measurements would prospectively predict poorer responses to treatment.

Neuropathic pain was evaluated in 58 individuals ${ }^{40}$ diagnosed with peripheral polyneuropathy and results pointed to the incidence of more catastrophic thoughts associated to less pain relief and higher probability of discontinuing drug therapy, reports of further incapacity and worse quality of life. Pain duration was negatively associated to probability of drug therapy success.

Sometimes there is influence of negative memories of previous symptoms and expectations influencing the perception of future symptoms, which could play a decisive role in the cognitive processing by magnifying it. Under this point of view, there are still few studies with regard to anatomofunctional aspects ${ }^{41}$.

So, the perceptive processing could help to better understand the condition, since there would be a 'sensory' processing aimed at perceptive analysis, cancellation and anticipation based on internal models during fine exploratory movements and a second processing, called 'executive' polymodal ${ }^{42}$, which would be associated to working memory, attention and decision-making processes used for conscious development of mental representation of a perceived object.

General cognitive processing, in such states, would involve the cerebellum differently from what has been seen to date ${ }^{43}$. Authors suggest that in addition to cortical structures, cerebellum regions could reflect that pain perception would be involved in signaling expected sensory consequences. So, functional connectivity would confirm previous results acquired with other forms of investigations, adding some ideas, such as "sensitive" cerebellum, especially part of sensory-motor cerebellum (and vestibular) and being also able to include areas used by visual, auditory and interoceptive processing ${ }^{44}$. In a study with neuropathic pain patients ${ }^{45}$ there has been no significant association among high pain intensity levels, cognitive and emotional evaluations and underlying pathology, and sensory neuropathic symptoms. Conclusions of this study were discussed in terms of possible differential response biases in patients with and without sensory neuropathic symptoms evaluated by clinical exam, medical exams or underlying pathology of the disease. Results of this study support the importance of using adjusted scores, eliminating response bias, when investigating neuropathic symptoms self-reported by patients.

So, they have not shown that sensory neuropathic symptoms intensity, or any pattern of such symptoms, have exclusively led to increased pain intensity, chronicity and negative affection. They have highlighted the fact that sensory symptoms self-reports were not necessarily associated to major neuropathic pain characteristics, but rather correlated to a trend to negative responses in patients without any identifiable underlying disease or sensory neuropathic symptoms.

More recently, the concept has been established that pain relief has to be more gratifying to activate brain motivational rewards circuits ${ }^{46}$.

Adaptations of reward circuits are critical for the maintenance of chronic pain pathology. Understanding the brain reward system processed in the context of pain may lead to the development of new therapies to treat emotional aspects of pain and comorbidities.

\section{Body image}

Appearance and body image have major impact on social and occupational lives of people in general. For individuals with plexular avulsion, discrimination is common: some try to disguise the appearance maintaining hands in pockets; others avoid using stings because this would call the attention to the incapacity and would generate questions forcing them to retell their history ${ }^{47}$.

Body image distortion may be important part of the presentation of some conditions, such as after amputation, tooth extraction, spinal cord injury, 
stroke, local anesthesia and complex regional pain syndrome type 1 . These individuals describe body image distortion as feeling the affected part larger, full or swelled, even when none of these characteristics are apparent ${ }^{48}$; however, mnemonic somesthesic changes are present and contribute for pain magnification, even in the absence of peripheral stimulus.

\section{Psychosocial factors}

Four psychosocial factors would drive symptoms amplification, including the belief that one has a severe disease, the expectation that the condition shall probably worsen, that is, catastrophizing thoughts, while psychosocial relational elements, including effects of possible litigations and/or compensations - conscious or unconscious - and alarming portrait of the condition as dramatic or tragic and debilitating outcome ${ }^{49}$.

Physical functioning refers to the organic potential of an organism to perform movements and other functions and is critical to the process of adapting to the environment and consequently to the development of chronicity in cases of painful syndromes. A major component of incapacity is physical functioning limitation imposed by neuropathic pain symptoms, associated to avoidance behaviors. For example: trigeminal neuralgia is a severe and debilitating facial pain which may be induced by light touches such as washing the face, shaving, vibration or teeth-brushing ${ }^{50}$.

Nervous injury induces motor and sensory deficits as well as other secondary problems which, associated to psychological factors may influence recovery, recurrence and return to work. It is also necessary to consider the possible presence of primary conditions such as diabetic neuropathy. A qualitative study has observed that people with diabetes types 1 and 2 would experience changes in feet, pain and insomnia, fatigue and mobility limitation, social isolation and solitude, a restricted life, loss of control and fear of the future ${ }^{51}$. A quantitative and qualitative study has evaluated people with post-herpetic neuralgia and their relatives. The objective was to evaluate the impact of herpes-zoster in daily activities of patients and their relatives. Results have shown that all participants expressed feelings of abandonment and frustration, mixed with depression, sadness or anger. Many have said that their lives had stopped, as compared to family members who said that their lives were occupied and stressing. Although patients would appreciate psychological and emotional support given by relatives, they underestimated the impact of their disease on them ${ }^{52}$.

Family union, that is, strong emotional relationship between members of a same family, influences patients' quality of life. A study has evaluated 103 patients with traumatic brachial plexus injury ${ }^{53}$. Scores of quality of life of the sample were lower than the standard and age, dominant side injury, upper limb function, intimacy and family income were all factors influencing quality of life.

Work, in addition to financial source, is integral part of individual identity, an important means of social action and recognition and is the basis on which each individual plans and projects his future. Limitations imposed by pain put in risk individual's social insertion and may lead him to dependence behaviors, isolation and discredit on part of the community.

At work, tasks in which people are involved may be stress-generator sources, because although meaning increased standard of life, working in industrial societies also exposes individuals to adverse conditions which may be associated to insertion in the organizational structure: excessive competitiveness, loss of autonomy in hierarchical systems, loss of understanding and value of the tasks due to job division, submission to the rhythm imposed by machines, submission to time pressure, among others; or related to physical working environment itself: transportation risks, chemical, radioactive and biological contamination risks; exposure to excessive noise, light, temperature and humidity, among others.

Discrimination due to pain, appearance or mobility limitation, limits job opportunities and progress on job, even if individuals are qualified. It may also be perceived when those having occupations involving intensive physical work try to return to them: few are effectively able to return or to find a new job, many are retired by incapacity and few look for a new area ${ }^{54}$.

Dependence on third-parties to perform sometimes the simplest tasks, decreases self-image and self-esteem, and many people with neuropathic pain do not like to ask for help: some because they do not want to bother, others because they believe that they have to develop means to recover their independence and many because they are ashamed of their limitation ${ }^{54,55}$.

A study has investigated the number of patients returning to work after unilateral lower limb amputation and the factors influencing this result ${ }^{56}$.
Participated in the study 100 patients in productive age with amputation at least one year before, and prostheses users. Just $66 \%$ of them had returned to work and this was related to mobility, time since amputation and incapacity scores.

Age, stump comfort, level and cause of amputation, previous type of work or the existence of other medical problems were not different between those returning or not to work. Although mobility is a relevant factor to return to work, lack of relationship with the level of amputation, other medical problems, stump comfort or previous job is contrary to expectations.

Social life of people involves many groups: friends, leisure, religion, etc. being that each one represents a social support aspect necessary for individual survival, however each group also requires participation bound by personal commitments and expressed by role-playing, which may often generate conflicts of difficult solution. There is a clear impact of neuropathic pain on education, leisure, occupational life and on roles in life $\mathrm{e}^{57,58}$.

\section{Stress theory}

Strong evidences of the stress model for the study of chronic pain stress the importance of maladaptive responses in the transition from acute affection to chronic pain ${ }^{59}$, with further recognition of the role of stress responses deregulating the transition toward pain maintenance, making it chronic, which would have major implications for the handling of prevention and management proposals $s^{60}$. Interventions aiming at relief or reversion of the allostatic load related to chronic pain could be as important as treating the nociception source per $\mathrm{se}^{61,62}$.

So, recent studies have confirmed that cultivating mental states aiming at down-regulation and external management of stress impact ${ }^{63}$, by means of different clinical interventions, should promote decreased stress and anxiety as critical for prevention and relief.

Painful experience is supported by muscular tension process, when almost instinctively motor reaction is a preparation aiming at solving the adverse event by means of stress reaction mechanism. Muscle tone is changed to prepare for action, that is, fight-escape-freezing responses.

In the attempt to avoid malaise to be extended, in the short term, muscle tension reaction and pain contention, the idea is that it should be extended and avoid even more the adverse response and, with this, the result might be worsening. In the long term, avoidance mechanism, induced by sustained continuation seems to worsen it and involves adjacent areas as feedback mechanism.

Drug treatment may interfere with this feedback mechanism, however, with the learning of behavioral strategies, via awareness of feedback eliciting and maintaining mechanism it is well possible that behavioral reactions are changed, where the automatic reaction is started so that there is less effect of the action controlled by knowledge of the effect of its responses on the stressor cycle.

Focusing on immediate attention to the adverse stimulus may seem to patients that painful stimulus might even increase, because when proposing awareness there might be increased perception of the phenomenon and in parallel tension is shifted to other events as important or even more important than the painful event and when two events with equal importance compete, attentive mechanisms tend to match perception to each one of them ${ }^{64}$.

Perception of sensations in general is not easily identified in Western society, since "it is suffering and not pain, which takes patients to medical treatments". Only the study of integrated brain function will end up leading to its accurate understanding and adequate management of pain ${ }^{5}$. Finally, the interpretation of pain experience needing management.

\section{Coping}

Coping, concept proposed by Lazarus, may be defined as "all cognitive and behavioral efforts which constantly change to deal with requirements (...) evaluated as overloading or exceeding individual resources" ${ }^{65}$ which, in case of pain, would be all cognitive and behavioral efforts to deal with or manage it.

It is a process going on along time and aimed at administering or modulating relationships between the individual and his environment. A longitudinal exploratory study ${ }^{66}$ has followed coping strategies of people with spinal cord injury for one year and has found that pain coping strategies and other psychological factors remained stable in a period of 2 to 12 months after injury. Initially, pain intensity and unpleasant aspects were considered inde- 
pendently, but after 6 months, they were correlated with pain severity, with interference in daily life and with catastrophizing.

Living with pain requires continuous adaptation effort and forces individuals to produce and experience a series of cognitive and behavioral strategies aimed not only at controlling pain unpleasant sensation, but also at coping with difficulties and changes in daily life, resulting from the chronicity of their condition.

Coping depends on individual resources. As from these resources, chronic pain individuals need to create and implement strategies to deal with the discomfort of the sensation, with incapacity, with procedures, treatments and institutions; to maintain adequate relationships with health professionals, relatives and friends; to preserve emotional balance and a satisfactory self-image, among others.

Coping strategies are based on evaluation of situations: situations evaluated as amenable to change tend to produce strategies consisting in planned actions to change the situation, be it acting on the environment or on yourself; situations evaluated as not amenable to change tend to produce strategies to control emotions, discomfort or perturbation related to the situation, without however changing it ${ }^{65,67}$.

With this, psychosocial, psychotherapeutic and psychopharmacotherapeutic behavioral therapies should contribute both to explain structural bases and to daily pain management, inducing patients to better relief scores.

\section{Brief psychiatric considerations}

The American Psychiatric Association in its $5^{\text {th }}$ edition of the Diagnostic and Statistical Manual of Mental Disorders - DSM-5), has replaced previous categories of somatoform disorder, hypochondria, painful disorder and undifferentiated somatoform disorder by "somatic symptoms disorder (SSD) with predominantly somatic complaints" and "SSD with pain characteristics" 68 .

Diagnosis is characterized by "anguishing somatic symptoms added of abnormal thoughts, feelings and behaviors in response to these symptoms" ${ }^{\prime \prime}$. It is important to notice that previous requirement that symptoms would have to be medically unexplainable was removed from the new version and that psychological symptoms paired with somatic symptoms were added including excessive symptoms of thoughts, feelings or behaviors related to somatic complaints or associated to concerns with health, manifested by the rumination and/or high level of anxiety about health, or symptoms and/or excessive time and energy dedicated to symptoms or health concerns.

In all these ways of thinking about chronic pain associated to multiple somatic symptoms, there is the underlying theme of incapacity to objectively evaluate symptoms expressed by patients ${ }^{69,70}$.

A recent study states that pain, depression and/or anxiety coexist and mutually exacerbate themselves in clinical and pre-clinical findings, seeming to be a reciprocal causal relation where the concept of interaction of domains may promote future development of new comorbidity models between pain and depression ${ }^{69}$.

Modern psychiatry observes that in many psychopathological presentations, neuroinflammatory process contributes for the development and maintenance of the condition. With this, there would be better structured justifications for the co-occurrence of diseases such as depression, anxiety and pain $^{71-73}$.

Amygadala plays important role in the emotional-effective dimension, be it in pain conditions ${ }^{74-76}$ and in daily life and, through interactions with corti$\mathrm{cal}$ areas, also contributes to cognitive aspects such as deficits on decisionmaking with regard to pain.

\section{CONCLUSION}

Although not being possible to consider that the addressed subject has runned out with this study, this chapter is considered as "Final Considerations" and not as "Conclusion", since psychobehavioral and psychosocial aspects of neuropathic pain are of extreme importance and comprehensiveness not being possible to exhaust them in this review. Current literature reveals numerous points of view on the issue.

Other more recent aspects are driving readers to the core of general treatment, that is that psychological factors which before were admitted as 'reactions to pain' are now seen as integral part of the painful process and as such should make up the general treatment of the condition.
These should be considered as condition conduction pathway and, for a long time it is recognized that pain treatment, from psychological science point of view, is a major component of psychological and general control and management, based on reaching relief through active participation of patients, encouraging them toward heath care, in addition to fostering active participation in the psychosocial sphere. And, remembering that the old dilemma is still to be defined whether psychobehavioral problems would be cause or reaction to pain, but anyway, psychological management is still critical for general treatment.

\section{REFERENCES}

1. Cozolino L. The neuroscience of psychotherapy: Building and rebuilding the human brain. New York: WWW Norton \& Company Inc: 2002.

2. Linden DE. How psychotherapy changes the brain - the contribution of functional neuroimaging. Mol Psychiatry. 2006;11(6):528-38.

3. Turk DC, Audette J, Levy RM, Mackey SC, Stanos, S. Assessment and treatment of psychosocial comorbidities in patients with neuropathic pain. Mayo Clin Proc. 2010;85(3 Suppl):S42-50.

Bellissimo A, Tunks E. Chronic pain: the psychoterapeutic spectrum. New York: Praeger; 1984. 97p. Loeser JD. Pain and suffering. Clin J Pain. 2000;16(2 Suppl):S2-6.

5. Loeser JD. Pain and suffering. Clin J Pain. 2000;16(2 Suppl):S2-6.
6. Perissinotti DMN. Dor "psicogencia: mito ou realidade? http://www.dol.inf.br/html/Repensando/ Perissinotti DMN. Dor
DorPsicogenica.html

DorPsicogenica.html
Papini MR, Fuchs PN, Torres C. Behavioral neuroscience of psychological pain. Neurosci Biobehav Rev. 2015;48(2):53-69.

8. Woolf CJ, Mannion RJ. Neuropathic pain, aetiology, symptoms, mechanisms and management. Lancet. 1999;353(9168):1959-64.

9. Bennett MI. Theories, history and current taxonomy. In: Bennett MI. (editor). Neuropathic pain. Oxford: University Press; 2006. 3-9p.

10. Treede RD, Jensen TS, Campbell JN, Cruccu G, Dostrovsky JO, Griffin JW, et al. Neuropathic pain: redefinition and a grading system for clinical and research purposes. Neurology. 2008;70(18):1630-5.

11. Bennett MI, Smith BH, Torrance N, Lee AJ. Can pain can be more or less neuropathic? Comparison of symptom assessment tools with ratings of certainty by clinicians. Pain. 2006;122:289-94.

12. Torrance N, Smith BH, Bennett MI, Lee AJ. The epidemiology of chronic pain of predominantly neuropathic origin. Results from a general population survey. J Pain. 2006;7(4):281-9.

Melzack R. From the gate to the neuromatrix. Pain. 1999;(Supp 6):S121-6.

14. Thacker M, Moseley GL, Flor H. Neuropathic pain. Management is more than pills. BMJ. 2009;1:339:b3502.

15. Moseley GL, Vlaeyen JW. Beyond nociception: the imprecision hypothesis of chronic pain. Pain. 2015;156(1)35-8

16. Crofford LJ. Chronic pain: where the body meets the brain. Trans Am Clin Climatol Assoc 2015;126:167-83.

17. Perissinotti DMN, Figueiró JAB, Fortes SL. Procedimentos Psicoterápicos para o tratamento da dor. In: Teixeira MJ, Figueiró JAB. Dor: epidemiologia, fisiopatologia, avaliaçăo, síndromes dolorosas e tratamento. Sáo Paulo: Moreira Jr; 2001. 141-9p.

18. Morris D. The Culture of Pain. Berkeley: University of California Press; 1991.

19. Ahrold J. Providing valuable input. Pract Pain Manag. 2001;24-6.

20. Flor H. Painful memories. Can we train chronic pain patients to 'forget' their pain? 2002;3(4):288-91

21. Eisenberger NI, Lieberman MD. Why rejection hurts: a common neural alarm system for physical and social pain. Trends Cogn Sci. 2004:8(7):294-300.

22. Eisenberger NI. Broken hearts and broken bones: a neural perspective on the similarities between social and physical pain. Curr Direct Psychol Sci. 2012;21(1):42-7.

23. Kross E, Berman MG, Mischel W, Smith EE, Wager TD. Social rejection shares somatosensory representations with physical pain. PNAS. 2011;108(15):6270-5.

24. Flor H. Cortical reorganization and chronic pain: implications for rehabilitation. J Rehabil Med 2003;(41 Suppl 6):66-72.

25. Hahamy A, Sotiropoulos SN, Henderson Slater D, Malach R, Johansen-Berg H, Makin TR. Normalisation of brain connectivity through compensatory behaviour, despite congenital hand absence. Elife. 2015;4.

26. Erdelyi MH. Explicit and implicit memory. In: Barth B, Giampieri-Deutsch P, Klein HD. (editors) Sensory perception: mind and matter. NY: Springer Verlag; 2012. 275-91p.

27. Erdelyi MH. Explicit and implicit memory. In: Barth B, Giampieri-Deutsch P, Klein HD. (Editors). Sensory perception: mind and matter. NY: Springer Verlag; 2012. 275-91p.

28. Sleutjes A. Dor, Atençáo e Memória. In: Portnoi A (Org.). A Psicologia da Dor. São Paulo: Guanabara Koogan; 2014. 131-7p.

29. Attal N, Masselin-Dubois A, Martinez V, Jayr C, Albi A, Fermanian J, et al. Does cognitive functioning predict chronic pain? Results from a prospective surgical cohort. Brain. 2014:137( $\mathrm{Pt} 3$ 3):904-17.

Del Nero HS. O Sítio da Mente: Pensamento, Emoção e Vontade no Cérebro Humano. São Paulo: Collegium Cognitio; 1997.

31. Moseley GL, Gallace A, Spence C. Bodily illusions in health and disease: physiological and clinical perspectives and the concept of a cortical "body matrix". Neurosci Biobehav Rev. 2012;36(1):34-46.

32. Berryman C, Stanton TR, Bowering KJ, Tabor A, McFarlane A, Moseley GL. Do people with chronic pain have impaired executive function? A meta-analytical review. Clin Psychol Rev. 2014;34(7):563-79.

33. Berryman C, Stanton TR, Bowering KJ, Tabor A, McFarlane A, Lorimer Moseley G. Evidence for working memory deficits in chronic pain: a systematic review and meta-analysis. Pain. 2013;154(8):1181-96.

34. Park HD, Tallon-Baudry C. The neural subjective frame: from bodily signals to perceptual consciousness. Philos Trans R Soc Lond B Biol Sci. 2014;369(1641):2-8.

35. Gross JJ, Munōz RF. Emotion regulation and mental-health. Clin Psychol-Sci Pr. 1995;2:151-64.

36. Ochsner KN, Silvers JA, Buhle JT. Functional imaging studies of emotion regulation: a synthetic review and evolving model of the cognitive control of emotion. Ann N Y Acad Sci, 2012;1251:E1-24. Crofford LJ. Adverse effects of chronic opioid therapy for chronic musculoskeletal pain. Nat Rev Rheumatol. 2010;6:1917.

38. Portnoi AG, Simurro SA, Andrade DC, Okada M, Teixeira MJ. Avaliaçáo psicológica de um caso de insensibilidade congênita à dor. Rev Dor. 2007;8(2):1028-36.

39. Mankovsky T, Lynch ME, Clark AJ, Sawynok J, Sullivan MJL. Pain catastrophizing predicts poor response to topical analgesics in patients with neuropathic pain. Pain Res Manage. 2012;17(1):10-4. . Toth C, Brady S, Hatfield M. The importance of catastrophizing for successful pharmacological treatment of peripheral neuropathic pain. J Pain Res. 2014;7:327-38.

41. Apkarian AV, Bushnell MC, Treede RD, Zubieta JK. Human brain mechanisms of pain perception 
and regulation in health and disease. Eur J Pain. 2005;9(4):463-84.
Nicholl BI, Macfarlane GJ, Davies KA, Morriss R, Dickens C, McBeth J. Premorbid psychosocial factors are associated with poor health-related quality of life in subjects with new onset of chronic widespread pain — results from the EPIFUND study. Pain 2009;141(1-2):119-26.

43. Baumann O, Borra RJ, Bower JM, Cullen KE, Habas C, Ivry RB, et al. Consensus paper: the role of the cerebellum in perceptual processes. Cerebellum. 2015;14(2):197-220.

44. Gustin SM, Peck CC, Cheney LB, Macey PM, Murray GM, Henderson LA. Pain and plasticity: is chronic pain always associated with somatosensory cortex activity and reorganization? J Neurosci. 2012;32(43): 14874-84.

45. Shaygan M, Böger A, Kröner-Herwig B. Neuropathic sensory symptoms: association with pain and psychological factors. Neuropsychiatr Dis Treat. 2014:10:897-906.

46. Navratilova E, Atcherley CW, Porreca F. Brain circuits encoding reward from pain relief. Trends Neurosci. 2015;38(11):741-50

47. Franzblau LE. A Qualitative Study of the Adult Patient's Experience after Complete Avulsion Traumatic Brachial Plexus Injury: Subjective Outcomes and Implications for Patient Educations. (undergraduate senior thesis) University of Michigan, 2013.37p.

48. Moseley GL. Distorted body image in complex regional pain syndrome. Neurology. 2005;65(1):773.

49. Barsky AJ, Borus JF. Functional somatic syndromes. Ann Intern Med. 1999;130(11):910-21.

50. McMillan R. Trigeminal neuralgia - a debilitating facial pain. Rev Pain. 2011;5(1):26-34

51. Ribu L, Wahl A. Living with diabetic foot ulcers: a life of fear, restrictions, and pain. Ostomy Wound Manage. 2004;50(2):57-67.

52. Weinke T, Glogger A, Bertrand I, Lukas K. The societal impact of herpes zoster and postherpetic neuralgia on patients, life partners, and children of patients in Germany. Scientific World J. 2014;749698.

53. Shen J, Wang Z-W. The level and influencing factors of quality of life in patients with brachial plexus injury. Int J Nurs Sci. 2014;1:271-5.

54. Franzblau LE, Maynard M, Chung KC, Yang LJ-S. Medical treatment decision making after total avulsion brachial plexus injury: a qualitative study. J Neurosurg 2015; 122:1413-1420.

55. Novak CB, Anastakis DJ, Beaton DE, Mackinnon SE, Katz J. Biomedical and psychosocial factors associated with disability after peripheral nerve injury. J Bone Joint Surg Am. 2011;93(10):929-36.

Fisher K, Hanspal RS, Marks L. Return to work after lower limb amputation. International J Rehabil Res. 2003;26(1):51-6.

57. Chemnitz A, Dahlin LB, Carlsson IK. Consequences and adaptation in daily life - patients' experiences three decades after a nerve injury sustained in adolescence. BMC Musculoskelet Disord. 2013; $14: 252$.

58. Machado AG, Baker KB, Plow E, Malone DA. Cerebral stimulation for the affective component of neuropathic pain. Neuromodulation. 2013;16(6):514-8.

59. Borsook D, Maleki N, Becerra L, McEwen B. Understanding migraine through the lens of maladap- tive stress responses: a model disease of allostatic load. Neuron. 2012;73(2):219-34

60. Luine V, Villegas M, Martinez C, McEwen BS. Repeated stress causes reversible impairments of spatial memory performance. Brain Res. 1994;639(2):167-70.

61. Rodriguez-Raecke R, Niemeier A, Ihle K, Ruether W, May A. Brain gray matter decrease in chronic pain is the consequence and not the cause of pain. J Neurosci. 2009;29(44):13746-50.

62. Seminowicz DA, Wideman TH, Naso L, Hatami-Khoroushahi Z, Fallatah S, Ware MA, et al. Effective treatment of chronic low back pain in humans reverses abnormal brain anatomy and function. J Neurosci. 2011;31(20):7540-50

63. Davidson RJ, McEwen BS. Social influences on neuroplasticity: stress and interventions to promote well-being. Nat Neurosci. 2012;15(5):689-95.

64. Sprenger C, Eippert F, Finsterbusch J, Bingel U, Rose M, Büchel C. Attention Modulates Spinal Cord Responses to Pain. Curr Biol. 2012;22(5):1019-22.

65. Lazarus R, Folkman S. Stress, appraisal, and coping. New York: Springer; 1984

66. Taylor J, Huelbes S, Albu A, Gómez-Soriano J, Peñacoba C, Poole HM. Neuropathic pain intensity, unpleasantness, coping strategies, and psychosocial factors after spinal cord injury: an exploratory longitudinal study during the first year. Pain Med. 2012;13(11):1457-68.

67. Smith JC. Stress, the Life Span, and the Family. In: Smith JC. Understanding Stress and Coping Macmillan Publishing Company, New York, 1993. 169-91p.

68. American Psychiatric Association. Diagnostic and Statistical Manual of Mental Disorders - DSM-5. Washington, D.C.: American Psychiatric Publishing; 2013

69. Jun-Xu Li. Pain and depression comorbidity: A preclinical perspective. Behav Brain Res. 2015;276(1):92-8

70. Katz J, Rosenbloom BN, Fashler S. Chronic pain, psychopathology, and DSM-5 somatic symptom disorder. Can J Psychiatry. 2015;60(4):160-7.

71. Burke NN, Finn DP, Roche M. Neuroinflammatory mechanisms linking pain and depression. Mod Trends Pharmacopsychiatri. 2015;30:36-50.

72. Burke NN, Geoghegan E, Kerr DM, Moriarty O, Finn DP, Roche M. Altered neuropathic pain behaviour in a rat model of depression is associated with changes in inflammatory gene expression in the amygdala. Genes Brain Behav. 2013;12(7):705-13.

73. Walker AK, Kavelaars A, Heijnen CJ, Dantzer R. Neuroinflammation and comorbidity of pain and depression. Pharmacol Rev. 2014:66(1):80-101.

74. Neugebauer V, Li W, Bird GC, Han JS. The amygdala and persistent pain. Neuroscientist. 2004;10(3):221-34.

75. Veinante P, Yalcin I, Barrot M. The amygdala between sensation and affect: a role in pain. J Mo Psychiatry. 2013;1(1):9.

76. Neugebauer V, Galhardo V, Maione S, Mackey SC. Forebrain pain mechanisms. Brain Res Rev. 2009;60(1):226-42. 